\title{
A Critical Analysis on Pension Fund Performance: An Assessment in the Perspective of Political Economy of Accounting
}

\author{
Gaguk Apriyanto ${ }^{1}$, Eko Ganis Sukoharsono ${ }^{1}$, Gugus Irianto ${ }^{1} \&$ Erwin Saraswati ${ }^{1}$ \\ ${ }^{1}$ Doctoral Program of Economics and Business Faculty, Brawijaya University Malang, Indonesia \\ Correspondence: Priyono, Post Graduate Program PGRI Adi Buana University, Surabaya, Indonesia. E-mail: \\ priyono.unu_sidoarjo@yahoo.com
}

Received: November 6, 2015

Accepted: November 26, 2015 Online Published: January 23, 2016

doi:10.5539/ijbm.v11n2p141

URL: http://dx.doi.org/10.5539/ijbm.v11n2p141

\begin{abstract}
This study aims to assess the performance of the Pension Fund based on the perspective of Political Economy of Accounting (PEA). This study is a multiple case study analysis, with three (3) study sites, Pension Fund A, B, and $\mathrm{C}$.

The results showed that the financial performance of the Pension Fund A is excellent, but the hegemony and domination of the employer and the board of trustees is quite high, resulting in the detriment of the interests of pension fund in the form of delay to raise pension benefits. The financial performance of the Pension Fund B is good, yet hegemony and dominance of the employer and the board of trustees is quite high, resulting in the detriment of the interests of pension fund in the form of a decrease in the value of pension benefits. The financial performance of the Pension Fund $\mathrm{C}$ is not good, hegemony and domination of the employer and the board of trustees is high enough, which harms the interests of the pension fund in the form of increased pension benefits and transparency of fund management information. The situation illustrates that hegemony and domination has occurred by employers and administrators in the Pension Fund A, B, and C. The three pension funds have failed to provide justice and prosperity to the retired people.
\end{abstract}

Necessary is regulations to reduce the hegemony and domination of employers and board of trustees of pension funds, so that the distribution of power and wealth is more equitable.

Keywords: performance, political economy of accounting, power distribution, welfare distribution, hegemony

\section{Research Background and Problems}

The existence of pension funds is needed, in particular to provide welfare benefits to employees when they retired. In the United States, the provision of pension benefits made through company's defined benefit pension plans, defined contribution pension plan, as well as hybrid or mixed pension plan (Clark, 2004, p. 1). Pension funds are one of the most important supporting institutions to provide social protection to the majority of citizens (Emmerson, 2003; Munell, 2003). Philosophically, the pension fund system is moving most resources obtained during the work life to postretirement when income is no longer obtainable (income dries up) (Muralidhar, 2001, p. 1).

The development of pension funds today, especially in Indonesia, is very good. This is apparent from investment activities by the Pension Fund. From 2009 to 2012, there has been a shift in the investment of pension fund, previously dominated by short-term investment instrument replaced by long-term investment instrument. During 2012, the portion of long-term investment of pension funds reached $70.96 \%$ of total investment (FSA, 2013, p. $16)$.

In the assessment of performance, especially in the pension fund industry, the elements of pension fund has the potential to reduce the interests of employees (Riza, 2003, p. 9). Interests or rights of employee take form of payment of pension benefits in a timely, easy to access information particularly with respect to transparency in the management of pension funds, as well as the types of rights of others. Therefore, it is unfair if the assessment of performance to pension funds only uses the financial performance approach, which consists of Return on Investment (ROI) with SPI, Return on Investment (ROI) without SPI, SPI, the average efficiency, and Fund Adequacy Ratio (RKD) to DPPK-PPMP. Return on Investment (ROI) with SPI, Return on Investment (ROI) without SPI, SPI, and average efficiency, for DPPK-PPIP (Pension Fund Info, 2013). The performance assessment mentioned above has not been able to express the values of distributive justice. Therefore, we need 
another perspective in the assessment of performance of pension funds, namely performance assessment perspective to reveal the distribution of justice, both power distribution and wealth distribution.

After seeing the model of performance assessment above and characteristic in the pension fund industry, that the main purpose of pension funds is to provide welfare benefits to retired people as well as in the management of pension funds, the high enough dominance of the role of employers and board of trustees of pension funds, then in the assessment of the performance of pension funds, it is appropriate to use PEA perspective, as this perspective can reveal aspects of distributive justice, better distribution of power and of welfare of the employer, pension fund board of trustees and pension fund participants as stakeholders.

This research will apply the theory of classical PEA in Pension Fund A, Pension Fund B, and Pension Fund C. The reasons the author chose the Theory of Political Economy of Accounting (PEA) as an analytical tool is because this theory is able to reveal aspects of the fairness of distribution of power and welfare (Cooper and Sherer, 1984, p. 207). Based on the description of the background, the research problem is on the concept of performance assessment of Pension Fund A, B and C by using a combination of method of Baldrige Assessment and theory of Political Economy of Accounting (PEA).

\section{Research Methodology}

This study uses a critical paradigm. Critical paradigm is a research paradigm that sees a critical reality as an object of research. This research paradigm sees the reality that occurs not in accordance with what should be happening in the community. Reality is the primary object of research paradigms critically. So that in ontology, where reality also happens to researchers and occurs outside researchers. Epistemology critical paradigm states that the distance of researchers with the object of research is very close, researchers are directly involved with the object under study. Researchers look at the suitability and correctness of the theory with praxis that exist in reality. Critical paradigm is inspired by critical theory that is often associated with theories inspired by Marxism and mostly raised by the members of the Frankfurt school such as Jürgen Habermas.

The research was conducted in Pension Fund A, B, and C. The reasons for choosing the three study sites mentioned above, because the researchers did not encounter any significant difficulties to obtain research data on these three sites, as researchers become one of the administrators in Association of Indonesia Pension Fund Commissariat Region VI of East Java and the surrounding areas. The ease of accessing data in the research field shall become a consideration (Morse in Denzin \& Lincoln, 1988, p. 60). The unit of analysis in this study is the practice of performance assessment on pension fund from the perspective of Political Economy of Accounting (PEA).

Instrument in this study is the main thing so that research can be done. Researchers become the main instrument in this study, in this case as data collectors. Data collected by researchers through direct observations to the field at any given time. This research was supported by instrument such as cameras, recording devices, and so on, so that the collected data is sufficient to complete the study and achievement of research goals.

The main data source in this study was the informant. Informant is essentially the subject of research, because of the informant research data will be obtained and is also expected to provide feedback on research data in order to cross check the data. Selection of informants is done deliberately, based on criteria described by Bungin (2003, p. 54), that the informant is an individual who has a long and intensive blend with the activity or field as the target of research.

Table 1. Research informants

\begin{tabular}{llll}
\hline Informant Identity & Position in Organization & Pension Funds \\
\hline 1. & $\mathrm{Ah}$ & Employer & $\mathrm{A}$ \\
2. & $\mathrm{Su}$ & Trustee & \\
3. & $\mathrm{Sa}$ & Member & \\
4. & $\mathrm{Ma}$ & Member & $\mathrm{B}$ \\
1. & $\mathrm{Ba}$ & Employer & \\
2. & $\mathrm{Wi}$ & Trustee & \\
3. & $\mathrm{Gi}$ & Trustee & \\
4. & $\mathrm{Di}$ & Member & $\mathrm{C}$ \\
5. & $\mathrm{St}$ & Member & \\
1. & $\mathrm{Sk}$ & Employer & \\
2. & $\mathrm{Fi}$ & Trustee & \\
3. & $\mathrm{Wk}$ & Member & \\
4. & $\mathrm{Yu}$ & Member & \\
5. & $\mathrm{Mi}$ & Member & \\
\hline
\end{tabular}


In order to obtain the necessary data, researchers used data collection techniques of documentation, observation, and interviews. Researchers did involve themselves directly in the situation being investigated as a pure observer and systematically observe the various dimensions exist, including interactions, relationships, actions, events, and so on (Mason, 1996, p. 60). Observations made on real activity, can also be done by watching video footage or photographs (Sutopo, 2002, p. 65). Related to this observation, researchers would prefer the observation on the activity of well-structured and randomized interviews. Randomized interviews were done to the informants randomly, whereas in a structured interview, the researcher did the interviews with well-prepared materials to obtain the expected data.

To know the various interested parties and the extent of their influence on the level of fairness of distribution of rights of pension fund, the researchers use an analysis tool of Political Economy of Accounting (PEA). Political Economy of Accounting (PEA) used in this study is one of the analytical tools of critical theoretical approaches.

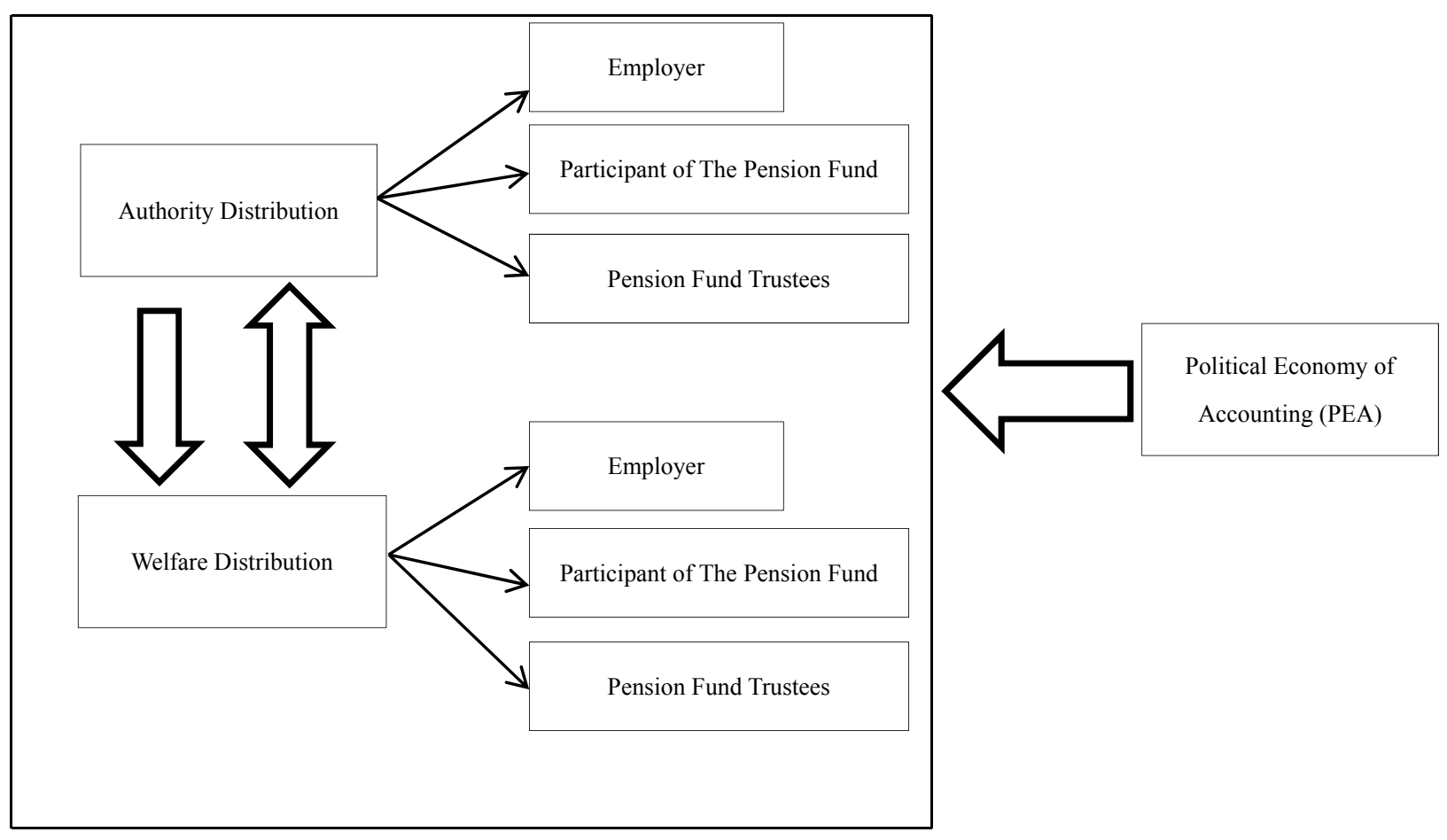

Figure 1. Model of analysis

\section{Theoretical Review of Political Economy of Accounting}

Another performance assessment method is the Political Economy of Accounting (PEA). This method assesses performance from the justice aspect of the distribution of power and prosperity. In the neo-classical economic view, an element of profit is the main element (bottom line) of business activity, which is used as a tool to measure the efficiency of the production process. This is in contrast with the views of classical political economy that profit is a reflection of the power owned by the owners of capital. The implication is that the greater the profits from the company, then the greater the power held by the investors (the company owners). It shows that the group has a great power will gain greater profits from operating companies (Tinker, 1980, 1984). In addition to power, classical political economy of fairness also sees the distribution of wealth or welfare (just and fair distribution of wealth). The underlying view of classical political economy is that profit from the company is an indicator of the firm's market viability and also as a tool to measure the social efficiency in utilizing society's resources, and not a technical measure of efficiency in the conversion of input to output (Tinker, 1980, p. 147; Tinker et al., 1982; Neimark \& Tinker, 1986, pp. 374-76; Irianto, 2006, p. 19). This view provides a new understanding of the function of capital that the function of capital is not only as a physical instrument of the production process, but also as a medium of social relations in the production process (Bhaduri, 2002, p. 200; Tinker, 1980, p. 153). Thus PEA analysis shows that the greater the power owned by the owners of capital, the greater the share of wealth or well-being that will be obtained (Tinker, 1980; Hoogvel \& Tinker, 1978; Irianto, 2006; Irianto, 2007). 


\section{Critical Exploration of Pension Fund A, B and C}

\subsection{Pension Fund A}

\subsubsection{Findings Related to Employer}

The statement about the importance of the role of the employer in this pension fund is delivered by one of the following employers:

Because the form of a pension fund is a pension fund by employer, the employer's role is central (Ah, 2013).

The statement of pension fund trustees about the attitude of employers who have procrastinated approval on the increase in the value of pension benefits, which at the time the condition of the capital adequacy ratio has reached the first level.

Pension Fund A wants to raise the retirement benefits as the capital adequacy ratio has reached the first level, yet commissioner did not want to sign and always delay ( $\mathrm{Su}, 2012)$.

The statement about the attitude of employers who objected to raise pension benefits is stated by the following trustee:

Board always finds it difficult to ask employers to raise the pension benefits ( $\mathrm{Su}, 2013$ ).

A statement of the directors of PT A Tbk decided that employees of PT A Tbk, which began to be accepted in 2008, were not included as participants of the Pension Fund A, but included in the Pension Fund or DLPK. The finding is submitted by one of the trustees following a Pension Fund:

Starting in 2008, all new employees are not included in the defined benefit pension plans, but included in defined contribution plan or DPLK; if they are included into a defined benefit pension plan, they will burden the employer (Ah, 2013).

\subsubsection{Findings Related to Trustees}

Statement concerning the application of GPFG by trustees in Pension Fund A is delivered by one of the Board of the Pension Fund Trustees below:

Our Pension Fund until now has not implement GPFG as a whole, because the transaction is not as complex and large as other pension funds such as Telkom Pension Funds, Bank Mandiri Pension Funds 1 and 2, or the Pertamina Pension Fund (Su, 2013).

\subsubsection{Findings Related to Pension Fund Participants}

The statement regarding the pension fund's concern over the management of pension funds is delivered by one of the following participants:

We are too busy with work, so we do not think too much about the pension fund. I trust it to pension fund trustees (Ma, 2013).

The statement of one of the passive participants related to information management of pension funds by pension fund trustees to the pension fund participants as one of the stakeholders, is delivered by a passive participant or retired person, as follows:

When I was a participant in the pension fund, I did not really know about the financial condition of the pension funds, especially after retirement, I now know nothing (Sa, 2013).

The statement related to the acquisition of information, especially about the condition of the subsidiary of PT A Tbk through bulletin received routinely is delivered by a passive participant as follows:

After I retired, although not regularly, I receive bulletins from the subsidiary of Pension Fund A, not from PT A Tbk (Sa, 2013).

The statement on the employer, in this case PT A Tbk, related to increasing the income of employees, instead of increasing the basic salary, the increase is from the components of allowances.

The basic salary of employees of PT A Tbk was small, yet the allowance is large. Though the size of the pension benefit amounts depend on the size of the basic salary, the pension benefit is small ( $\mathrm{Sa}, 2013)$.

\subsection{Pension Fund B}

\subsubsection{Findings Related to Employer}

The statement regarding the functions of the supervisory board is as follows:

The supervisory board is busy. We, the trustee board, find it difficult to see them (Wi, 2013). 
The statement regarding late payment by the employer due to funding difficulties, the following statement from the employer represents this condition:

Pension fund trustees must be aware of the financial condition of the employer. The financial condition of the employer determines the sustainability of pension fund (On, 2013).

The statement regarding one of the obligations of the employer, namely the payment of dues to the pension fund is submitted by one of the pension fund trustees. The statement is as follows:

It happened in the year 2009, the founder paid the fee late. Main dues were already paid, the fine was then in installment. Until now, the late fee is still not paid. If there is a problem with the payment of pension benefits to participants, employers ask to finish it, so the employee do not protest (Wi, 2013).

The statement regarding the obligations of PT B as an employer in the Pension Fund B for the losses experienced by pension funds caused by the economic crisis in 2008 , delivered by one of the following trustee:

In 2008, the pension fund of PT B experienced losses due to the economic crisis (not the fault of the board). The board asked the employer to cover such losses as it coincided with the payment of pension benefits whose value plummeted, but the employer was not willing to cover the losses. As a result, the participants protested to the board of the pension fund (Gi, 2013).

\subsubsection{Findings Related to Trustees}

The statement about the implementation of good governance such as the following:

For the application of good governance, not all of the 16 principles could be implemented here, because the pension fund PT B is not too big. Our asset is only about IDR 100 billion. The investment is simple, not involving a lot of activities and smaller operational costs. 16 guidelines are for the policy to be optimal (Wi, 2013).

\subsubsection{Findings Related to Pension Fund Participants}

The statement regarding the transparency of the management of pension funds by pension fund trustees is as follows:

We asked for transparency in managing the pension fund, not to repeat what happened in the past, when the pension benefits are paid, the amount is not in accordance with what we expect. We, as participants of the pension funds,are severely impaired (Street, 2013).

\subsection{Pension Fund C}

\subsubsection{Findings Related to Employer}

The statement regarding the functions of the supervisory board of the Pension Fund C which is not optimal in its function and lack of knowledge of the supervisory board on the pension fund is delivered by one of the administrators as follows:

The Board of Supervisory is too busy with the main job, so they cannot perform their functions properly. Besides, they lack of knowledge related to the pension fund ( $\mathrm{Fi}, 2013)$.

Funding ability of the employer and funding obligations to the pension fund is high enough, and the board is required to meet the targets set by the technical interest actuary of $12.5 \%$ annually, as stated in the following:

Because of the actuarial target of technical interest, which is $12.5 \%$, which is too high, then the trustees do aggressive investment strategy, in which most of the investment is in the capital market (Fi, 2013).

Pension fund trustees deliver the statement on investment recommendations of employer as follows:

There are several investment recommendations given to the employer; and almost all the recommendations are high-risk investments that result in losses for pension funds (Fi, 2013).

The statement about the rights of employees as participants in the pension fund, the $\mathrm{C}$ Foundation has determined that for the welfare of retired people, especially new employees recruited in 2011 are included as participants of Pension Fund (DPLK). This statement was made by the representative of the employer as follows:

Starting in 2011, new employees are not included in the defined benefit pension plans, but in defined contribution plan of DPLK. The new employees will become our burden shall they be included into defined benefit pension plans (Sk, 2013).

One of the employers delivers the statement on the basic salary of pension fund participants $\mathrm{C}$ : 
Employers want to increase salaries, but the increase is not in the basic salary, but in allowances (earning improvement). If the increase is on the basic salary component, it will increase in employer contributions to pension funds and more burden for the employer (Sk, 2013).

\subsubsection{Findings Related to Trustees}

The statement related to the functions of the board of trustees at the Pension Fund C is as follows:

The Board of Supervisory is too busy with the main job, so they cannot perform their functions properly. Besides, the supervisory board also lacks an understanding about pensions (Fi, 2013).

The statement related to the implementation of guidelines for the implementation of 16 policy guidelines of GPFG in the Pension Fund $\mathrm{C}$ is as follows:

Pension Fund $\mathrm{C}$ has small assets, so that pension fund trustees should not be carrying out the 16 policy guidelines of GPFG set by Bapepam -LK. If we carry out the guidelines, it will be inefficient (Sk, 2013).

\subsubsection{Findings Related to Pension Fund Participants}

The statement related to the rights of participants in the Pension Fund C, submitted by the pension fund participant, as follows:

I heard that our pension benefit is small. Please, increase it. I agree if they take more from my salary every month (Wk, 2013).

The statement related to the timing of payment of pension benefits in the Pension Fund $\mathrm{C}$ is delivered by one of the participants as follows:

The pension benefits should be directly paid when an employee retires (Yu, 2013).

The statement about the rights of participants in the Pension Fund C, particularly related to the development of the individual investments, is delivered by one of the pension fund participants, as follows:

If we as participants of the pension fund at any time need information, especially information related to the development of the investment portfolio, please serve us immediately (Mi, 2013).

The above statement is closely related to one of the rights of pension fund participants as one of the stakeholders to obtain information related to the transparency of pension fund management.

\subsection{Power, Welfare, and Hegemony Distribution}

The case of Pension Fund A, Pension Fund B, and Pension Fund C, we come to a lesson of a theory of class conflict, in which Marx filed a fundamental conception of society and the class struggle. Marx did not define a class at length, but he showed that in the community, in the 19th century in Europe where he lived, consisting of the capitalist class (bourgeoisie) and the poor working class as the proletariat. Both of these classes are in a hierarchical social structure, and bourgeois exploitation of the proletariat in the capitalist system of production. Several points can be noted from Marx's Theory of Conflict. First, the struggle for power is essentially between the bourgeoisie and the working class. Second, the struggle associated with the distribution of power and prosperity.

4.4.1 Power, Welfare, and Hegemony Distribution in Pension Fund A

In Pension Fund A, bourgeois actors are employers and trustees while the working class is the pension fund participants. The distribution of power in the Pension Fund A is reflected in the structure of employer contributions and the contributions of participants in the picture below. 


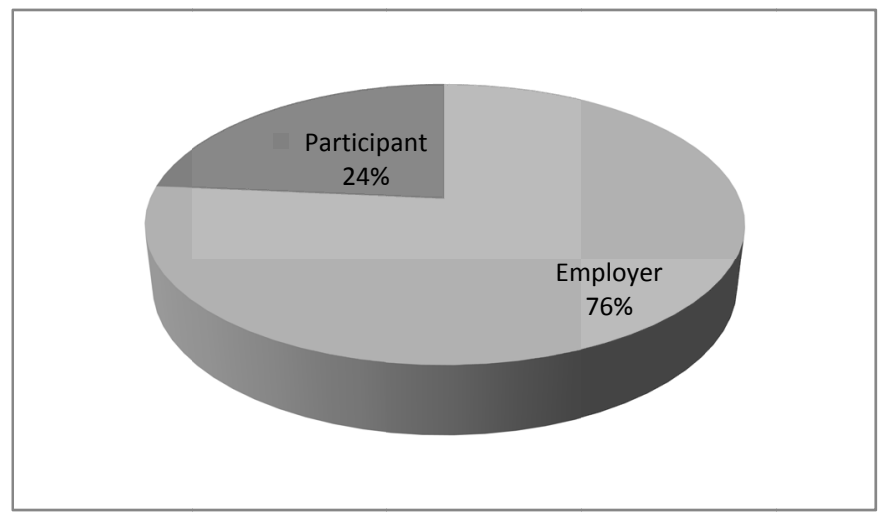

Figure 2. Power distribution pension Fund A

Power distribution of PT Tbk A as the employer of Pension Fund A is $76 \%$ of the total dues; the dues percentage is high enough, then the employer domination became quite large in the management of pension funds. First, the employer always procrastinate the approval on the increase of pension benefits, which at the time the condition of the capital ratio adequacy has reached the first level, which means Pension Fund had a surplus of funding which is quite high. The high surplus of the funding could be used to increase pension benefits. Delays in increase in the value of pension benefits show the negative attitude of the employer to be received by participants. An increased value of pension benefits will increase the employer contribution. Secondly, the defined benefit pension plan was burdensome to employer that the employer decides that since 2008, all new employees are not included in the defined benefit pension plans, but included in defined contribution plan or DPLK. Third, inaccuracies in payment of dues that dues received in 2012 were only IDR 1,359,626,096 (Pension Fund A's financial statement, 2012). As a result of the emergence of these receivables is reduction in investment income of pension funds. Fourth, if the employer objected to funding in the pension fund, the employer can apply to the Ministry of Finance to dissolve the pension fund (Law No. 11 of 1992 Section 33 (1)). If the pension fund is dissolved, then the most disadvantaged party is the pension fund participants. Fifth, establish and amend the Pension Fund. Sixth, appoint and dismiss the trustee board and the supervisory board.

Power distribution of the trustee board of Pension Fund A is reflected in the average percentage of salary of the board compared with the total operating costs from 2009 until 2012, as shown in the following table:

Table 1. Percentage of salary compared with the total operating costs of pension fund A

\begin{tabular}{ll}
\hline & Percentage \\
\hline 2009 & $76 \%$ \\
2010 & $72 \%$ \\
2011 & $76 \%$ \\
2012 & $75 \%$ \\
\hline
\end{tabular}

Power distribution of the Board of Trustee of Pension Fund A from 2009 to 2012 is on average $75 \%$ of total operating costs. With the percentage of salary that is high enough, then the dominance of pension fund trustees is high enough in the management of pension funds. First, the board did not fully implement the rules that exist in the GPFG. As for the reason for the board to not fully implement the existing rules in the GPFG because of the size of a pension fund, which is not big enough. This is certainly contrary to the appeal of the Capital Market Supervisory Agency and Financial Institution (Bapepam-LK), which requires all pension funds to construct and apply the Code and Governance Pension Fund, as stipulated in the Decree of the Chairman No. KEP-136 / BL / 2006 with the aim of encouraging the preparation of guidelines for good governance in the pension fund as well as providing a reference to the founder, the employer, pension fund administrators and supervisors. Second, it is making arrangements with a third party without the involvement of the supervisory board. Pension Fund A's administrators invest in particular sectors, so that the investment is safe, then the board needs to involve a third party such as a notary. Other activities which need to involve a third party, for example, an auditor to audit the 
financial statements and annual investment, and appraisal to assess the fixed asset investment. Third, take legal action for and on behalf of the Pension Fund and represents the Pension Fund in or out of court.

Based on the above explanation, an understanding that employers and trustees of Pension Fund A have sufficient power and potentially hegemonic to the pension fund management is obvious. Hegemony is a condition characterized by the practice to dominate and control the other parties in all aspects to achieve certain interests (Riduwan, 2010, p. 46). Hegemony also occurs in accounting practices created by the accountants to dominate and control the various stakeholders in the preparation, presentation and reading of financial reports (Cooper, 2006, p. 178). In Pension Fund A, the biggest hegemony made by the employer to the pension fund trustees and pension fund participants, while the smaller hegemony again performed by pension fund trustees on pension fund participants.

\subsubsection{Power, Welfare, and Hegemony Distribution in Pension Fund B}

In Pension Fund B, bourgeois actors are employers and trustees while the working class is the pension fund participants. The distribution of power in the Pension Fund B is reflected in the structure of employer contributions and the contributions of participants in the picture below.

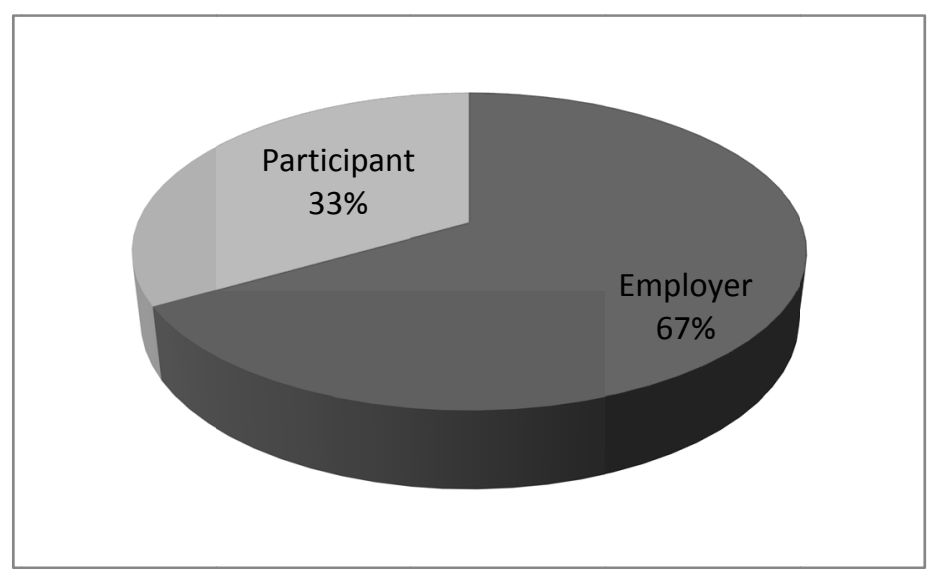

Figure 3. Power distribution pension fund B

Power distribution of Pension Fund B as the employer of Pension Fund is $67 \%$ of the total dues; the contribution percentage is high enough, then the employer domination became quite large in the management of pension funds. With such dominance, the Board of Directors of PT B as the employer would not cover the losses. Because of this loss, and by the time it coincided with pension benefit payments, then the value of the pension benefits received by participants decreased quite dramatically. This made pension fund participants to be not satisfied with the rights they receive, since the value was not as it should be. Secondly, employers did not want to pay the fine for late payment of dues. Third, inaccuracies in payment of dues, that dues received in 2012 was only IDR 312,254,291 (Pension Fund B's financial statement, 2012). As a result of the emergence of these receivables is reduction in investment income of pension funds. Fourth, if the employer objected to funding in the pension fund, the employer can apply to the Ministry of Finance to dissolve the pension fund (Law No. 11 of 1992 Section 33 (1)). If the pension fund is dissolved, then the most disadvantaged party is the pension fund participants. Fifth, establish and amend the Pension Fund. Sixth, appoint and dismiss the trustee board and the supervisory board.

Power distribution of the trustee board of Pension Fund B is reflected in the average percentage of salary of the board compared with the total operating costs from 2009 until 2012, as shown in the following table: 
Table 2. Percentage of salary compared with the total operating costs of pension fund B

\begin{tabular}{ll}
\hline & Percentage \\
\hline 2009 & $57 \%$ \\
2010 & $61 \%$ \\
2011 & $61 \%$ \\
2012 & $61 \%$ \\
\hline
\end{tabular}

Power distribution of the Board of Trustee of Pension Fund B from 2009 to 2012 is on average $60 \%$ of total operating costs. With the percentage of salary that is high enough, then the dominance of pension fund trustees is high enough in the management of pension funds. First, the board did not fully implement the rules that exist in the GPFG. As for the reason for the board to not fully implement the existing rules in the GPFG because of the size of a pension fund, which is not big enough. This is certainly contrary to the appeal of the Capital Market Supervisory Agency and Financial Institution (Bapepam-LK), which requires all pension funds to construct and apply the Code and Governance Pension Fund, as stipulated in the Decree of the Chairman No. KEP-136 / BL / 2006 with the aim of encouraging the preparation of guidelines for good governance in the pension fund as well as providing a reference to the founder, the employer, pension fund administrators and supervisors. Second, it is making arrangements with a third party without the involvement of the supervisory board. Pension Fund B's administrators invest in particular sectors, so that the investment is safe, then the board needs to involve a third party such as a notary. Other activities which need to involve a third party, for example, an auditor to audit the financial statements and annual investment, and appraisal to assess the fixed asset investment. Third, take legal action for and on behalf of the Pension Fund and represents the Pension Fund in or out of court (Act No. 11 of 1992, Article 10 paragraph (2)).

Based on the above explanation, an understanding that employers and trustees of Pension Fund A have sufficient power and potentially hegemonic to the pension fund management is obvious. Hegemony is a condition characterized by the practice to dominate and control the other parties in all aspects to achieve certain interests (Riduwan, 2010: 46). Hegemony also occurs in accounting practices created by the accountants to dominate and control the various stakeholders in the preparation, presentation and reading of financial reports (Cooper, 2006: 178). In Pension Fund B, the biggest hegemony made by the employer to the pension fund trustees and pension fund participants, while the smaller hegemony again performed by pension fund trustees on pension fund participants.

\subsubsection{Power, Welfare, and Hegemony Distribution in Pension Fund C}

In Pension Fund $\mathrm{C}$, bourgeois actors are employers and trustees while the working class is the pension fund participants. The distribution of power in the Pension Fund $\mathrm{C}$ is reflected in the structure of employer contributions and the contributions of participants in the picture below.

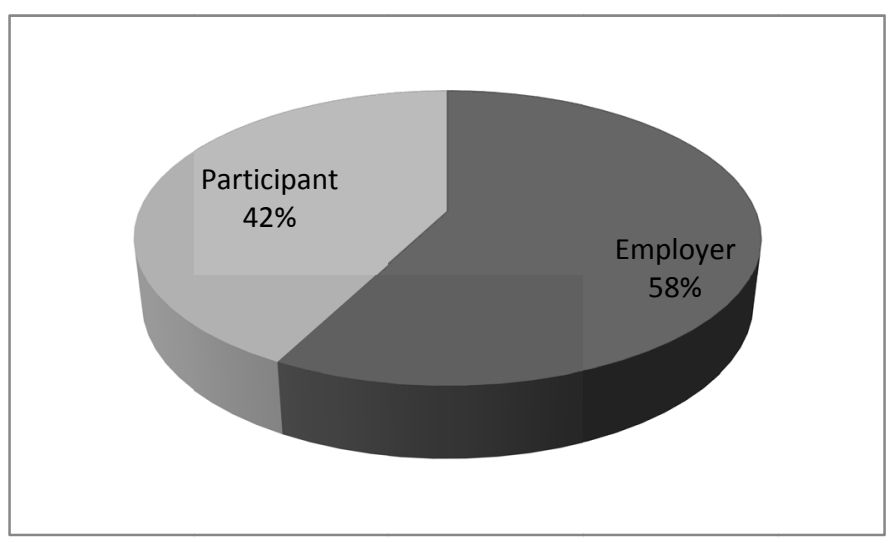

Figure 3. Power distribution pension fund $\mathrm{C}$

Power Distribution of Higher Education Foundation C as the employer of Pension Fund C is $58 \%$ of total contributions; the contribution percentage is high enough, then the employer domination became quite high in the management of pension funds. Some of the dominance of the employer is shown by the fact that the employer 
asked the Board to meet the targets set by the technical interest actuary of $12.5 \%$ annually (Appendix: 7 ). The high technical determination of the interest is due to the high ratio of the actuarial liabilities of the pension fund asset availability and that Higher Education Foundation of Merdeka Malang as the employer of Pension Fund C is not willing to cover part of the deficit in which the deficit is the difference between actuarial liabilities with available assets. Secondly, with the reason that defined benefit pension plan is burdensome to employer, the employer sets that since 2011 all new employees are not included in the defined benefit pension plans, but included in $\mathrm{m}$ defined contribution plan or DPLK. Third, inaccuracies in payment of dues, that dues received in 2012 was only IDR 32,640,454(Pension Fund C's financial statement, 2012). As a result of the emergence of these receivables is reduction in investment income of pension funds. Fourth, if the employer objected to funding in the pension fund, the employer can apply to the Ministry of Finance to dissolve the pension fund (Law No. 11 of 1992 Section 33 (1)). If the pension fund is dissolved, then the most disadvantaged party is the pension fund participants. Fifth, establish and amend the Pension Fund. Sixth, appoint and dismiss the trustee board and the supervisory board. Seventh, there are some investment recommendations given by the employer at the expense of pension funds because these investments turn problematic. Eighth, the employer is willing to increase the income of employees, under an agreement that the increase is on allowance components, not on the component of the basic salary. Increasing basic salary component will burden the employer, as it will have to increase the number of dues.

Power distribution of the trustee board of Pension Fund $\mathrm{C}$ is reflected in the average percentage of salary of the board compared with the total operating costs from 2009 until 2012, as shown in the following Table:

Table 4. Percentage of salary compared with the total operating costs of pension fund C

\begin{tabular}{ll}
\hline & Percentage \\
\hline 2009 & $42 \%$ \\
2010 & $40 \%$ \\
2011 & $58 \%$ \\
2012 & $42 \%$ \\
\hline
\end{tabular}

Power distribution of the Board of Trustee of Pension Fund c from 2009 to 2012 is on average $75 \%$ of total operating costs. With the percentage of salary that is high enough, then the dominance of pension fund trustees is high enough in the management of pension funds. First, the board did not fully implement the rules that exist in the GPFG. As for the reason for the board to not fully implement the existing rules in the GPFG because of the size of a pension fund, which is not big enough. This is certainly contrary to the appeal of the Capital Market Supervisory Agency and Financial Institution (Bapepam-LK), which requires all pension funds to construct and apply the Code and Governance Pension Fund, as stipulated in the Decree of the Chairman No. KEP-136 / BL / 2006 with the aim of encouraging the preparation of guidelines for good governance in the pension fund as well as providing a reference to the founder, the employer, pension fund administrators and supervisors. Second, it is making arrangements with a third party without the involvement of the supervisory board. Pension Fund C's administrators invest in particular sectors, so that the investment is safe, then the board needs to involve a third party such as a notary. Other activities which need to involve a third party, for example, an auditor to audit the financial statements and annual investment, and appraisal to assess the fixed asset investment. Third, take legal action for and on behalf of the Pension Fund and represents the Pension Fund in or out of court.

Based on the above explanation, an understanding that employers and trustees of Pension Fund A have sufficient power and potentially hegemonic to the pension fund management is obvious. Hegemony is a condition characterized by the practice to dominate and control the other parties in all aspects to achieve certain interests (Riduwan, 2010, p. 46). Hegemony also occurs in accounting practices created by the accountants to dominate and control the various stakeholders in the preparation, presentation and reading of financial reports (Cooper, 2006, p. 178). In Pension Fund B, the biggest hegemony made by the employer to the pension fund trustees and pension fund participants, while the smaller hegemony again performed by pension fund trustees on pension fund participants.

\section{Conclusion}

Thorough performance assessment concept that takes into account the distribution of power and prosperity is required. Based on the concept of the performance assessment, the Pension Fund A is excellent, but the hegemony and domination of the employer and the board of trustees is quite high, resulting in the detriment of the interests of pension fund in the form of delay to raise pension benefits. The financial performance of the 
Pension Fund B is good, yet hegemony and dominance of the employer and the boards of trustees are quite high, resulting in the detriment of the interests of pension fund in the form of a decrease in the value of pension benefits. The financial performance of the Pension Fund C is not good, hegemony and domination of the employer and the board of trustees are high enough, which harms the interests of the pension fund in the form of increased pension benefits and transparency of fund management information. The situation illustrates that hegemony and domination has occurred by employers and administrators in the Pension Fund A, B, and C. The reality mentioned above illustrates that although the performance assessment in Pension Fund A is excellent and Pension Fund $\mathrm{B}$ and $\mathrm{C}$ is good, but hegemony and domination by employers and administrators in happened in pension Fund A, B, and C. They have failed to deliver justice and prosperity to the pension fund participants. Necessary is regulations to reduce the hegemony and domination of employers and board of trustees of pension funds, so that the distribution of power and wealth is more equitable.

Financial Services Authority is the regulator overseeing the performance of the pension fund industry, and the researchers suggest the need to consider the aspect of power, prosperity and hegemony of the parties related to the pension fund in the assessment of performance. By taking into account the above-mentioned aspects, the assessment of the performance of pension funds are becoming more comprehensive and fairer.

\section{References}

Bhaduri, S. N. (2002). Determinants of Corporate Borrowing: Some Evidence from the Indian Corporate Structure. Journal of Economics and Finance, 26(2), 200.

Bungin, B. (2003). Qualitative Research Data Analysis, Understanding of Philosophical and Methodological to the Direction Control Model Application. Jakarta: PT. King Grafindo Persada

Clark, G. L. (2004). Pension fund governance 2: Asymmetrical in formation and regimes of regulation. Working Paper(revised). Oxford: School of Geography and Environment, Oxford University.

Cooper, D. J. (2006). Critical Theorizing in Strategic Management Accounting Reserach. The Social Sciences and Humanities Research Council and The Certified General Accountants of Alberta Wales.

Cooper, D. J., \& Sherer, M. J. (1984). The Value of Corporate Accounting Reports: Argument for a Political Economic of Accounting. Accounting Organization and Society, 9(3/4), 207-232.

Denzin, N. K., \& Lincon, Y. S. (1988). The Lanscape of Qualitative Res earch: Theoriesand Issues. London: Sage Publications.

Emmerson, C. (2003). Pension reform in the United Kingdom: Increasing the role of private provision? In G. L. Clarkand \& N. Whiteside (Eds.), Pension Security in the $21^{\text {st }}$ Century (pp. 168-192.). Oxford: Oxford University Press.

Hoogvelt, A., \& Tinker, A. M. (1978). The Role of Colonial and Post Colonial States in Imperialism-a Case Study of the Sierra Leone Development Company. The Journal of Modern African Studies, 16(1), 67-79.

Info Dana Pensiun. (2013). Directions Economy Indonesia 2014 Pension Fund Info Magazine, Issue 51. November-December 2013.

Irianto, G. (2006). Dilemma "Profit" and the Political Economy Framework Theory of Accounting (PEA). TEMA, 7(2), 141-153.

Munnell, A. (2003). Restructuring pensions for the 21st century: The United States Social Security debate. In G. L. Clarkand \& N. Whiteside (Eds.), Pension Security in the $21^{\text {st }}$ Century (pp. 193-224). Oxford: Oxford University Press.

Muralidhar, A. (2001). Innovations in Pension Fund Management. Stanford: Stanford University Press.

Neimark, M., \& Tinker, T. (1986). The Social Construction of Management Control System, Accounting. Organization and Society, 11(4), 369-395.

OJK. (2013). Directory statistics 2012 and 2013 Non Bank Financial Industry Pension Fund. Jakarta.

Riduwan, A. (2010). Semiotics Profit Accounting: Study of Critical-posmodernis Derridean. Journal of Accounting and Finance Indonesia, 7(1), 38-60.

Riza. Y. (2003). Effect of Distributive Justice, Procedural Justice, Commitment to aim and motivation against the Managerial Performance Budgeting. National Symposium Accounting, 707-719.

Sutopo, H. B. (2002). Qualitative Research Methodology. Surakarta: Eleven March University Press.

Tinker, T. (1980). Towards a political economic of accounting: An empirical illustration of the cambridge 
controversies. Accounting, Organization and Society, 5(1), 147-160.

\section{Copyrights}

Copyright for this article is retained by the author(s), with first publication rights granted to the journal.

This is an open-access article distributed under the terms and conditions of the Creative Commons Attribution license (http://creativecommons.org/licenses/by/3.0/). 